\title{
Issues of Information and Communication for New Managerial Approaches: the Challenges of the French Health System
}

\author{
Christian Bourret \\ Paris East University (France) - Research Team DICEN, CNAM - Paris, France
}

\begin{abstract}
Faced with the crisis of the Welfare State, France insists on a new territorialization of health management and develops tools based on ICT (Information and Communication Technologies). This crisis also concerns the methods of management and trust between all the actors.

Informational and communicational issues exist at different levels of the system with the challenges of traceability and interoperability. New uses of information for new managerial approaches can be considered, using interface organizations to overcome the divisions and promote cooperations. We aim at promoting a "Digital Humanism" adapted to the Health sector.
\end{abstract}

Keywords: information devices, communication processes, healthcare, networks, management, territories

\section{Introduction}

The crisis of the Welfare State has been exacerbated by the financial crisis which started in 2008 and has become a whole crisis in public finances (deficits and public debt).

Our works are related to specifically French interdiscipline of Information and Communication Sciences and examine the prospects (engineering concept) in terms of different logics (organizational, collective and individual) or tensions and interactions between all the stakeholders (individuals or groups of actors, but also socio-technical devices). As proposed by F. Bernard [2], we aim at articulating the issues of relationship, meaning, knowledge and action, but also of identity and power. Information is shaping the organizations that constitute relevant contexts for actions. These organizations are shaped by information, but also by communication, especially by negotiations [17].

We are interested in understanding the complexity defined by E. Morin and J.-L. Le Moigne [15], combining a systemic approach (focusing on the interactions between actors) and a constructivist approach about social construction of reality by the actors.

Our analysis is based on partnerships and works (students' reports, research contracts, ground observations...) developed around a Master in Management of Health and Social Organizations in cooperation with the EN3S (Higher National School in Social Security).

\section{The Crisis of the Welfare State: the Major Challenges}

\subsection{Deficits and Funding Issues}

The Welfare State gradually set up in developed countries from 1945 (creation of Social Security in France and National Health Service in the United Kingdom) has been in crisis for over thirty years. For about ten years in France, the Nation's social budget has proved to be higher than the State's budget and the deficits and debts have accumulated, now exceeding $85 \%$ of annual GDP. Health expenditures approach $12 \%$ of GDP in France (5\% in the early 1960s). 
The divisions (boundaries) found in all health systems, are particularly strong in France, between the State (Ministry of Health) and the Health Insurance ${ }^{1}$ between the hospitals (in their majority public organizations) and private GP in primary care, between fields of cure, care, health and social, between the different professions... and can be considered as an aggravating factor. The worsening financial constraints exacerbated the tensions. D. Carré [7] has analyzed the gradually established strategy of the culprit: health is presented as a source of costs and deficits and not as an investment.

We must situate these challenges in the broader context of the "new spirit of capitalism" [3] with the importance of projects, networks and innovation and quality's challenges.

\subsection{Attempts of Responses for Adaptation: New Managerial Territories and ICT Tools}

In France, the State being traditionally interventionist, the aim of modernization (through rationalization) has received the name of RGPP (General Review of Public Policies).

In the Health sector, adaptation efforts, since 1996, go together with a new policy of territorial management of Health (in France, rather late compared to most of its neighbours: Spain, Italy or Germany), with a new emphasis on the regional level, but mainly in the form of "deconcentration" of State services and not "decentralization" of powers towards regional councils (creation of ARH: Regional Agency for Hospitalisation) which are State levels of management. These measures were also followed by the establishment of a policy of Risk Management, particularly financial risk and new attention on the issue of fraud ${ }^{2}$.

The outcome was passing of the Law Hospital, Patients, Health and Territories in July 2009. The key measure was creation in mid 2010 of the Regional Health Agencies (ARS) regrouping ARH, State social services and some Health Insurance sectors.
These attempts, as in all other developed countries, have also largely been based on policies of computerization and information management, said to allow both controlling costs and improve services for a user renamed "customer". In 1998 the United Kingdom focused on the program Information for Health. In 2005, the US Government reform committee called the computerization of the Health sector ("Bringing the IT revolution to Healthcare") in the United States "Last Frontier".

The UK has relied heavily on the EHR (Electronic Health Record). France, since 2004, on the DMP or Personal Medical Record [4] supposed to ensure cost control and care safety.

In the hospital sector, 2007 and 2012 plans for hospitals have emphasized the development of Hospital Information Systems. France has opted for the T2A or payment per activity to finance the hospitals. Everywhere, productivity and performance are key words of change, erected into a dogma. Evaluation of all the activities has become essential, often presented as a quality approach. This is particularly the role of HAS or High Authority in Health.

\section{Central Issue of Trust and Crisis of a Form of Management}

\subsection{The Rise of Distrust}

The rise of distrust is the first observation [1]. The scandal about contaminated blood was strongly impressive in the 1990s. Now we have got the "Mediator" scandal (bad use of a drug). Distrust also concerns health professionals, including private GP in primary care paid by patients for each fulfilled act. What is unspoken is the refusal by these private doctors of any control by the insurance organizations. Implementation of the DMP revived fears of a control of their activity and, consequently, of their income by the Health Insurance.

A key challenge is to restore confidence among all stakeholders. The first problem to settle is that of "miscommunication" [23] restoring trust

\footnotetext{
${ }^{1}$ In France, in 1945, with the creation of the Social Security, the governance of the Health System (laws and edicts, control, strategies) given to the Ministry of Health was separated from the Health Insurance, recovering of the social contributions (employees and employers) managed differently in a "paritaire" way (by representatives of enterprises and trade unions).

2 The amount of frauds in 2010 would be between 10 and 20 billion Euros and they explain an important part of the deficits.
} 
between all partners, but also through sociotechnical devices as the DMP: for giving a real added value to the activity of the GP (no double entry of data, durability and reliability of data). The restoration of confidence is inseparable from the recognition of the role of all the actors. We have studied the case of physiotherapists in the Healthcare Network for babies bronchiolitis in Ile-de-France.

Interface organizations between primary care and hospitalization (Healthcare Networks, Health Pluriprofessions Homes, Hospitalization at home...) can help to build trust and cooperation between the different actors.

\subsection{Questioning the "Managerial Ideology"}

To rise confidence is the main challenge. $\mathrm{H}$. Mintzberg [14] has criticized the obsession with just a concern for quantitative efficiency and V. de Gaulejac described the "society sick of management" [12]. C. Dejours found that the work situations where some employees are forced to bend the rules to make the system work together with some excesses of the evaluation procedures can lead to forms of suffering at work [9].

L. Thevenot had pointed out the issue of "government by the standards". Quality initiatives are too often reduced to the rigid application of procedures, which distorts their nature. The results of RGPP are questionable [8]: the injunction to "do more with less" can lead to dead ends.

Criticism of the "managerial ideology" focuses on quality and evaluation processes, reduced to rigid application of strict standards of "reengineering" and "line management" where research productivity first means reduction of the workforce.

\subsection{Giving Meaning and Responsibility by Promoting Cooperation}

In the Health sector, under-staffing and budgetary constraints increased tensions, as in 2009, when it was decided by the Ministry of Health to consider the hospital as a business company. This was received by an important part of its staff as denial of its specificity, treating health like any other product and denial of public service missions and general interest.

A. Mayère, S. Grosjean and L. Bonneville [13] studied the rationalization of hospital organizations, with the injunction to cooperate, while individual results assessments undermine the old collective practices. A. Ogien studied "the hospital seized by quantification" [16]. These paradoxical situations can cause discomfort and pain at work [9]. Cooperation can not be decreed: it's first a matter of envy and not of fear.

The issue of the meaning of the activity is raised: to give meaning to work by restoring confidence, self esteem and recognition (legitimacy of the actions). This is particularly true in the Health sector where staff is faced with the distress of patients and sometimes death (emergency services, oncology, intensive care...). The purpose must be to construct shared meaning by the convergence of representations and redefining the notion of general interest.

The Health sector and especially the hospital sector (public hospitals or private clinics) is the heart of contradictory tensions resulting from the impact of different logics: logic of manager efficiency, sense of quality for health professionals, technicist logic of the perfect tool for engineers, logic of patients... All these logics have different goals and time frames, difficult to reconcile.

For F.-X. Schweyer [19], the French hospital is torn between costs (logic of management) and values (logic of health professionals and patients). The tension caused by the standards must be added. For us, the hospital is torn between standards, costs and values [4]. The future of the whole Health System depends on the challenge of reconciling them. All this can be facilitated by new uses of ICT.

\section{Informational Issues and Tools at Different Levels}

\subsection{Data Needs and Levels of Governance}

We distinguish three levels of informational issues: micro, meso and macro, corresponding to different information needs [4]. 
The micro level is the level of interactions between patients and health professionals in primary care. It is based on the use of professional software tools and computerized patient records (including DMP): issues of custody (care pathway of patients) and non-duplication of medical acts are essential. The personal data of patients are subject to special restrictive legislations (laws, edicts, European directives...) to protect confidentiality and privacy [5].

The second level (meso) concerns health organizations: hospitals, private clinics, nursing homes, pluriprofessions homes, healthcare networks, hospitalization at home... Their Information Systems deal both with patient data and with administrative and management data such as those of the PMSI (Medicalization Program of Information Systems) and the T2A. These data, in addition to those of countless surveys and reports, are provided by and for controlling organizations constituting the third level (macro): ARH and then ARS, HAS, Health Insurance, linked with the Ministry of Health and Social Security... for evaluation and certification and for the definition of national or regional health strategies (plans). This macro level corresponds to the governance of the whole Health System in its different components. So Health Insurance has a huge data warehouse: the SNIIR-AM (National Information System for Insurance Organizations) corresponding essentially to the data for the reimbursement of patients (mainly electronic sheets for care) results of payment by acts in primary care [5].

\subsection{The Challenges of Traceability and Interoperability}

The issues of connection and coherence of all the interconnected information systems, correspond to the major issues of traceability and interoperability, both technical (between different devices like Information Systems), but also semantic (between the languages and the words used) [11]. The socio-technical devices of mediation and information transmission of the Health system can be considered as ordinary "actants", as well as human actors, as proposed by the "sociology of translation", including the
Actor Network Theory, translated in French by M. Callon as Sociologie de l'Acteur Réseau or SAR [6].

Telemedicine has a special place. It allows the best use of all available expertises (telesurgery, diagnosis...) as well as monitoring activities or distance learning.

The challenge of connecting various information systems consists in the transformation from Hospital Information Systems to Health Information Systems at the regional level, through the development of Services Platforms. It is the challenge of better tools for decision support in the ARS and in the new national agencies set up at the same time: ASIP or Agency for Shared Information Systems in Health and ANAP or National Agency for Help to Performance in medical and social organizations, for HAS, and for the various organizations constituting the Health Insurance sector ${ }^{3}$.

\section{New Uses of Information for New Managerial Approaches}

\subsection{Interface Organizations and New Intermediation Devices}

E. Morin [15] and R. Sainsaulieu [20] outlined the need for "reliance" of our society. The Health Sector is particularly concerned. Interface organizations can provide spaces to promote trust and meaning around new uses of information and improvement of communication processes. They are based on specific devices such as call centers, medical records and information systems, which are beginning to be integrated into Services Platforms at regional level.

Recent ICT devices at national level have appeared like Sophia, dedicated to the support of the chronical diseases, helping doctors, patients and Health Insurance to cooperate. The United Kingdom has focused on NHS Direct which provides guidance and advice to patients, both by telephone and Internet. This innovative service has been imitated by Catsalut in Barcelona

\footnotetext{
${ }^{3}$ In France, Health Insurance sector corresponds to CNAMTS (Health Insurance for Salaried Workers), MSA (Social Mutuality in Agriculture) and RSI (Social Regime for Independent Professions).
} 
(Sanitat Respon). In France, the law only allows information and not referring patients to care facilities or remote diagnosis.

The creation of new interface organizations as part of a new policy of territorial network of Health management as the proliferation of new tools requires coherent and comprehensive strategy to avoid the risk of new boundaries created by various socio-technical devices: various shared medical records including DMP, but also cancer communicating record or DCC, pharmaceutical records, records of different healthcare networks...

\subsection{New Managerial Approaches?}

The quality must not be limited to standards and procedures. Give meaning could be studying words of actors at work to better understand the "iceberg of activity" of which we perceive only a limited part [9]. We are working on a new approach of evaluation or "sustainable" quality. For us, quality cannot be only reduced to quantitative indicators, standards and procedures. It must favour innovative and social recognition of the role of all the actors in the organization for building collective intelligence and not only measures of individual results. The notion of performance will be redefined by returning to the original meaning of "performer", in old French: accomplishment and help to development, improvement. For us, actually, quality is a form of organizational intelligence to build positive interactions and cooperation.

It will try to allay fears of an "Internet of Things" in which a human becomes only a digital object to be connected to other non-human objects. We must not fall into the nostalgia of a sterile past. For M. Doueihi [10], the whole challenge is building a "Digital Humanism... result of a convergence between our cultural heritage and a complex technique that has become an unprecedented place of sociability". He particularly values the role of platforms: "they are essential, not because they manage access and storage, but because they have become through the activities of users... points of convergence between information, communication, knowledge and social skills".

\section{Conclusion}

More generally, by placing ourselves in the footsteps of J. Stiglitz, who denounced the excesses of the market economy [21] and P. Rosanvallon, proposing to "rethink the Welfare State" [18], we try to work for an alternative approach, an approach where quality is a mindset, a desire for improvement that cannot be reduced to quantitative indicators and standards. It is a form of Organizational Intelligence. This approach gives meaning to cooperative work and to public interest, but is also aware of the financial constraints and the need to improve productivity with the use of the ICT devices. It links challenges of new and better use of information with the improvement of communication processes.

It will give back all their sense to solidarity and social cohesion. It will also have the political will to tackle private interests and lobbies for real reforms. Are the fees for medicine service called liberal (act payment) always appropriate? With the creation of ARS, has the separation between the Ministry of Health and the Health Insurance still meaning?

ICT tools have an important role to play. But the tools are just tools. The important thing is the meaning (intended or not) that comes from their use. Particularly in Health, "Digital Humanism" is important to promote.

\section{References}

[1] Y. Algan, P. Cahuc, La société de défiance: comment le modèle social français s'autodétruit. Editions de la rue d'Ulm - Cepremap, Paris, 2007.

[2] F. BERNARD, “Les SIC une discipline de l'ouverture et du décloisonnement", in Bouzon A., dir., La communication organisationnelle en débat. Champs, concepts, perspectives, Paris, L'Harmattan, 2006, pp. $33-46$.

[3] L. Boltanski, E. ChiAPEllo, Le nouvel esprit du capitalisme. Gallimard-Essais, Paris, 1999, rééd., 2011.

[4] C. BourRet, Dynamiques organisationnelles autour de la production collective d'information et de processus communicationnels. Le cas des organisations d'interface du secteur santé, (Habilitation à Diriger des Recherches), Mayère A. dir., Université Paris Est, 2010, 2 vol. 
[5] C. BourReT, 'The implementation of Information Systems as major stake in the development of innovative organizations of interface to improve the French Healthcare System. Proceedings (Full Papers) IADIS Annual Conference e-Society, (2009) Barcelona, pp. 307-315.

[6] M. CAllon, Sociologie de l'Acteur Réseau. In Sociologie de la traduction: Textes fondateurs (M. AKRICH, M. CALlON ET B. LATOUR), (2006) pp. 267-276. Presses de l'Ecole des Mines de Paris.

[7] D. CARRÉ, Trois postures communicationnelles en santé: désingularisation, culpabilisation et imposition. In Communication et Santé: enjeux contemporains (C. RouTIER, A. D’ARRIPE, ÉD.), (2010) pp. 273-280. Presses Universitaires du Septentrion, Lille.

[8] F. Cornut-Gentille, C. ECKert, rapport d'information sur L'évaluation de la révision générale des politiques publiques (RGPP), Assemblée Nationale, 2011, consultable sur: http: //www . assembleenationale.fr/13/rap-info/i4019.asp

[9] C. DEJOURS, L'évaluation du travail à l'épreuve du réel, INRA Editions, Paris, 2010.

[10] M. DoueIHI, Pour un humanisme numérique. Seuil, Paris, 2011.

[11] M. FIESCHI, La gouvernance de l'interopérabilité sémantique est au cœur du développement des systèmes d'information en santé, rapport ministre de la Santé, Paris, 2009, consultable sur: http://lesrapports.ladocumentationfrancaise.fr/BRP/094000394/0000.pdf

[12] V. DE GaUlejaC, La société malade de la gestion. Idéologie gestionnaire, pouvoir managérial et harcèlement social, Paris, 2005.

[13] A. Mayère, S. Grosjean, L. Bonneville, Rationalisation des organisations hospitalières: des incitations économiques aux injonctions à collaborer, Rationalisation des organisations hospitalières, Sciences de la Société, n. 76, 2009, pp. 3-14.

[14] H. MinTZBERG, Le Management. Voyage au centre des organisations, Ed. d'Organisation, Paris, 2001.

[15] E. Morin, J.-L. Le Moigne, L'intelligence de la complexité, L'Harmattan, Paris, 2003.

[16] A. OGIEN, L'hôpital saisi par la quantification. Une analyse de l'usage gestionnaire de la notion de qualité, Rationalisation des organisations hospitalières, Sciences de la Société, n. 76, 2009, pp. $31-52$.

[17] L. L. Putnam, A. M. NiCOTERA, ED., Building Theories of Organization. The Constitutive Role of Communication, Routledge, New York and London, 2009.

[18] P. Rosanvallon, La nouvelle question sociale. Repenser l'Etat-providence, Paris, Le Seuil, 1998.
[19] F.-X. SCHWEYER, "Hôpital, une tension entre coûts et valeurs", in Halpern C. coord., La Santé. Un enjeu de société, Auxerre, Ed. Sciences Humaines, 2010, pp. 278-287.

[20] R. SAinsaulieu R, Des sociétés en mouvement. La ressource des institutions intermédiaires, Desclée de Brouwer, Paris, 2001.

[21] J. E. STigLiTZ, Un autre monde. Contre le fanatisme du marché, Fayard, Paris, 2006.

[22] L. THÉVENOT, Un gouvernement par les normes. Pratiques et politiques des formats d'information. In Cognition et information en société (B. CONEIN ET L. THÉVENOT, DIR.), (1997) pp. 205-242. Editions de l'EHESS, Paris.

[23] D. Wolton D, Informer n'est pas communiquer. CNRS Editions, Paris, 2009.

Received: June, 2012 Accepted: August, 2012

Contact address:

Christian Bourret Paris East University (France) - Research Team DICEN CNAM - Paris Ile-de-France Institute of Services Engineering (Paris East Marne-la-Vallée University) France e-mail: bourret@univ-mlv.fr

CHRISTIAN BOURRET (HDR) graduated from HEC (the most important French Business School) in 1978. He obtained PhD in Human and Social Sciences from Paris 7 University (1991) and Habilitation to Manage Research (HDR) in Information and Communication Sciences from Paris East University (2010).

He was a research engineer in CNRS (French Centre National de Recherche Scientifique) from 1980 to 2001 in Scientific Information and Research Valuation. Since 2001, he is senior lecturer of Information and Communication Sciences at the French University of Marnela-Valleee. Since October 2006, he is Director of the Ile-de-France Institute in Services Engineering (IFIS) at the University of Paris East Marne-la-Vallée (France). He manages a Master degree study in Social and Sanitary Organizations Management since 2007 in cooperation with the French National School in Social Security Insurance (EN3S). He belongs to the DICEN Research's Team in the CNAM (Paris) and Marne-la-Vallée. He has published two books on Human Sciences, 15 articles on information and communication sciences, 5 chapters in international scientific books (Wiley, Hermès-Lavoisier...) and 45 proceedings papers. He is a reviewer for international rewiews in Information and Comunication Sciences. His research topics concern Health Sector, particularly interfaces organisations such as Healthcare Networks in France with their information and communication challenges and comparisons with other countries. He works for other networked organizations in Social Welfare and their ICT (Information and Communication Technologies) issues: Information Systems, call centers, cooperative platforms, shared medical records... He particularly works on evaluation and quality processes (data quality...) and also on competitive and territorial intelligence issues (health, training, culture and territorial intangible capital...).

Dr Bourret belongs to various Research Communities: in Competitive and Territorial Intelligence (INTI: International Network for Territorial Intelligence), Projectics (Project Management), Codata (Committee on Data for Science and Technology), RESER (European Community for Research in Sevices) and SFSIC (Société Française des Sciences de l'Information et de la Communication). 